\title{
AKSESIBILITAS PEREMPUAN TERHADAP INFORMASI PEMANFAATAN PEKARANGAN DI KABUPATEN MINAHASA SULAWESI UTARA
}

\section{Women's AccessibilityOn InformationOn Utilization of Home Gardening in Minahasa regency of North Sulawesi}

\author{
Conny N Manoppo ${ }^{1 *}$ dan Yenny Oktavia² \\ ${ }^{1}$ Balai Pengkajian Teknologi Perta nian Balitbangtan Sulawesi Utara \\ ${ }^{2}$ Universitas Andalas Padang \\ *email koresponden: connybptpsulut17@gmail.com
}

\begin{abstract}
Abstrak
Akses informasi memiliki peran yang sangat penting pada berbagai kegia tan manusia tanpa terkecuali perempuan. Pera $\mathrm{n}$ informasi bagi diri perempuan adalah untuk membuka dan memperluas wa wasan berpikirperempuan terha dap sega la aktivitas yang dihadapi. Ana lisis faktor aksesibilitas terhadap informasi pemanfaatan pekarangan dan pen golahan hasil pangan mencakup: tingkat ketersediaan informasi pemanfaatan pekarangan dan pengolahan pangan, kesesuaia n informasi yang diterima, serta kredibilitas pemberiinformasi. Penelitian dilaksanakan bulan Maret 2015 sampai dengan Dese mber 2015. Lokasi penelitian di 12 Kecamatan Kabupaten Minahasa Provinsi Sula wesi Utara. Jumlah sampel seb anyak 140 ora ng. Da ta yang diperoleh dieksplorasi, dita bulasi dalam bentuk tabel frekuensi, dan dianalisis seca ra deskriptif. $\mathrm{H}$ asil analisis menunjuk kan, aksesibilitas terhadap ketersediaan informasi pemanfaatan pekarangan dan pengolahan pan gan berka tegori tersedia, namun jenis danjumlah informasi masih kurang tersedia. Kesesuaian informa si y a ng diterima mengenai pemanfaatan pekarangan dan pengolahan pangan bersumberdari pekarangan, berada dalam kate gori se su ai. Kredibilitas pemberi informasi berkategori kurang kredibel. Implikasi kebijakan yang bisa dilakukan adalah: memperbanyak informasi tentang pemanfaatan pekarangan dan pengolahan pangan yang bersumber dari pekarangan mela lui media cetak, elektronik (ra dio dan televisi) serta cyber ex tension, termasuk media sosial, peningkatan kredibilitas petugas pemberi informasi.
\end{abstract}

Kata kunci: Aksesibilitas Informasi, Pemanfaatan Pekarangan

\begin{abstract}
Information is very important in women activities. The role information to open and broaden of women's thinking towards all activities. Analysis of accessibility information on home gardening are: the level of information availability, suitability of information received, and credibility of informants. The study was conducted in March until December 2015. The research was conducted in Minahasa District. The sample consisted of 140 respondents. The data were analyzed using descriptive. The results show that accessibility of information availability is available, but the type and amount of information is still less available. The suitability of information received is appropriate category. The credibility of informants is categorized as less credible. The policy implications can be madeare: increasing information about the home gardening and processing of food sourced from the home garden, electronic (radio and television) media and cyber extensions, including social media, increasing the credibility of informants.
\end{abstract}

Keywords: Information Accessibility, Home gardening Utilization 


\section{PENDAHULUAN}

Aksesibilitas menurut kamus besar Bahasa Indonesia dimaknai sebagai hal yang dapat dijadikan akses. Aksesibilitas (accessibility) didefinisikan oleh (Warpani, 2002) sebagai tingkat kemampuan untuk mencapai atau mendapatkan barang dan jasa yang diperlukan. Okwu dan Umoru (Andriaty \& Setyorini, 2012) menyatakan, pendidikan dan pendapatan berhubungan nyata dengan tingkat aksesibilitas perempuan terhadap informasi pertanian. Ketersediaan dan kredibilitas sumber informasi serta sarana akses informasi juga akan menentukan kebutuhan informasi pengguna. Glendenning et al. (Andriaty, Sankarto, \& Setyorini, 2011) menyatakan, penyediaan informasi dan pemanfaatannya oleh petani dipengaruhi oleh beberapa faktor, yaitu: (1) kemampuan penyuluh dalam mencari dan memberikan informasi serta mendapatkan umpan balik dari petani; (2) keandalan (reliabilitas), relevansi, kegunaan, dan ketepatan waktu dari informasi yang diberikan; (3) proses pemanfaatan informasi yang selanjutnya dapat menentukan efektivitas informasi dan pemanfaatannya; dan (4) kesesuaian teknologi dengan kebutuhan petani.

Informasi menurut kamus besar Bahasa Indonesia adalah: penerangan; pemberitahuan; kabar atau berita tentang sesuatu; serta keseluruhan makna yang menunjang amanat yang terlihat dalam bagianbagian amanat itu. (Suprayitno, 2011) menyatakan, informasi adalah kegiatan pengumpulan atau pengolahan data sehingga dapat menghasilkan pengetahuan dan keterangan baru. Informasi teknologi termasuk usaha pemanfaatan pekarangan memegang peran penting dalam upaya mencukupi keanekaragaman bahan pangan. Ilmu pengetahuan dan teknologi tidak akan dapat dengan mudah dimanfaatkan, apabila informasinya tidak dihimpun, diolah, dan disajikan dengan baik, sesuai dengan harapan dan keinginan pengguna. (Lubis, 2010) mengatakan, informasi pertanian merupakan salah satu faktor yang paling penting dalam produksi dan tidak ada yang menyangkal bahwa informasi pertanian dapat mendorong ke arah pembangunan yang diharapkan.

Akses informasi sangat penting bagi petani tidak terkecuali perempuan. Peningkatan akses informasi bagi para petani dapat berdampak pada semakin meningkatnya kemandirian petani. Akses perempuan terhadap informasi pemanfaatan pekarangan sebagai sumber bahan pangan bagi keluarga merupakan hal yang sangat penting untuk ditingkatkan, karena akan meningkatkan kemampuan perempuan tani dalam memanajemen usahataninya guna memenuhi kecukupan pangan rumah tangga. Akses terhadap informasi pertanian dan pemanfaatannya dapat mendukung keberhasilan usahatani yang dikelola oleh petani. Persoalannya, tidak semua petani dapat mengakses dan memanfaatkan informasi dengan cepat dan tepat.

Perempuan dapat mengakses perkembanganperkembangan teknologi sesuai dengan kondisi usahataninya. Melalui akses informasi pasar mereka juga dapat mengetahui apa dan berapa kebutuhan konsumen, serta dapat memprediksi berapa yang mereka harus produksi dan dengan tingkat kualitas hasil yang seperti apa, sehingga harga jual yang diperoleh menjadi lebih baik. Adanya informasi modal juga sangat membantu mereka untuk mengembangkan usaha agribisnisnya menjadi lebih baik.

Menurut (Parikesit, 2003), akses adalah tingkat kesulitan atau kemudahan penduduk untuk memperoleh barang atau jasa yang dibutuhkan. World Bank (Hayati, 2015) mengatakan bahwa sangat penting untuk memberikan akses perempuan tani yang lebih besar ke informasi karena dapat mempengaruhi peningkatan kemampuan perempuan tani dan partisipasi perempuan tani dalam memelihara ketahanan pangan rumah tangga. Selanjutnya (Hubeis, 2012) juga menegaskan bahwa, ketidaktahuan dan ketidakmampuan perempuan tani dalam mengakses informasi pertanian terkini acap menghambat kemajuan perempuan tani dan kontribusi mereka pada ketahanan pangan rumah tangga. Berhasil atau tidaknya penerapan teknologi pemanfaatan pekarangan juga dipengaruhi oleh 
seberapa besar informasi itu bisa diakses oleh perempuan pemanfaat pekarangan. Menurut (Suryantini, 2004) tersedianya berbagai informasi teknologi pertanian akan mempercepat kemajuan usaha pertanian.

Perempuan memerlukan beragam informasi untuk mendukung usahataninya. Informasi yang dibutuhkan tidak hanya informasi praktis tentang teknologi produksi tanaman, tetapi juga informasi mengenai pascapanen (pengolahan, penyimpanan dan penanganan pasca panen) dan pemasaran. (Ban \& Hawkins, 1999) mengatakan, petani membutuhkan informasi teknologi tepat guna, serta informasi manajemen teknologi, termasuk penggunaan input yang optimal, pilihan berusahatani (usahatani campuran dan diversifikasi, peternakan, perikanan), sumber pemasok input, tindakan kolektif dengan petani lain, permintaan konsumen dan pasar, spesifikasi kualitas produk, waktu membeli input dan menjual produk, pendapatan luar pertanian (offfarm), implikasi dari perubahan kebijakan (subsidi input, liberalisasi perdagangan), akses terhadap kredit dan bantuan, pengelolaan sumber daya alam yang berkelanjutan, dan perubahan iklim. (Mulyandari \& Ananto, 2005) menyatakan, untuk mengelola usahatani dengan baik, petani memerlukan pengetahuan dan informasi mengenai hasil penelitian, pengalaman petani lain, situasi mutakhir yang terjadi di pasar input dan produk pertanian, dan kebijakan pemerintah.

Menurut Gonzales (Syafiuddin \& Jahi, 2008) ada tiga efek dari informasi yang disebarkan dengan cara komunikasi massal yaitu: kognitif, afektif dan konatif (psikomotorik). Efek kognitif meliputi, peningkatan kesadaran, belajar dan tambahan pengetahunan. Efek afektif berhubungan dengan emosi, perasaan dan sikap (attitude), sedangkan efek konatif terkait dengan perilaku dan niat untuk melakukan sesuatu tindakan menurut cara tertentu. Faktor-faktor yang perlu dipertimbangkan untuk mengelola informasi yang telah diperoleh menurut (Kaye, 1997) adalah: relevansi, akurasi, kelengkapan, ketajaman, ketepatan waktu, dan keterwakilan.

Aksesibilitas informasi pemanfaatan pekarangan adalah aktivitas yang dilakukan oleh perempuan untuk meraih pesan/pengetahuan yang terkait dengan usaha pemanfaatan pekarangan yang dilakukan. Informasi pemanfaatan pekarangan dan pengolahan pangan bersumber dari pekarangan dapat diperoleh dari penyuluh ataupun petugas lapangan lainnya. Semakin mudah aksesibilitas terhadap informasi yang dapat diakses oleh perempuan pemanfaat pekarangan, akan mempercepat proses adopsi suatu teknologi optimalisasi pemanfaatan pekarangan.

Aksesibilitas terhadap informasi dalam penelitian ini adalah kemudahan perempuan dalam berinteraksi dengan berbagai informasi tentang pemanfaatan pekarangan baik melalui kontak personal maupun melalui media. Tujuan penelitian adalah menganalisis tingkat aksesibilitas perempuan terhadap informasi pemanfaatan pekarangan. Faktor aksesibilitas terhadap informasi pemanfaatan pekarangan dan pengolahan hasil pangan dalam penelitian ini mencakup: tingkat ketersediaan informasi pemanfaatan pekarangan dan pengolahan pangan, kesesuaian informasi yang diterima, serta kredibilitas pemberi informasi.

\section{METODE PENELITIAN}

Penelitian dilaksanakan pada bulan Maret 2015 sampai dengan Desember 2015. Lokasi penelitian di 12 kecamatan Kabupaten Minahasa Provinsi Sulawesi Utara. Kabupaten Minahasa sebagai lokasi kasus dipilih dengan pertimbangan bahwa lokasi tersebut merupakan lokasi pelaksana program: Percepatan Penganekaragaman Konsumsi Pangan (P2KP) dan Model Kawasan Rumah Pangan Lestari (MKRPL).

Populasi penelitian adalah perempuan pemanfaat pekarangan yang tergabung dalam kelompok wanita tani, yang telah mengikuti Program Model Kawasan Rumah Pangan Lestari (MKRPL) dan Percepatan 
Penganekaragaman Konsumsi Pangan (P2KP) sejumlah 421 orang. Unit analisis adalah rumah tangga. skala Likert dengan empat skala: rendah (Skala 1), sedang (Skala 2), tinggi (Skala 3) dan sangat tinggi (Skala 4). Pada setiap butir pernyataan dalam

Tabel 1 Proporsi sampel berdasarkan lokasi dan jumlah rumah tangga (KK) di Kabupaten Minahasa

\begin{tabular}{llllll}
\hline No & \multirow{2}{*}{ Kecamatan } & $\begin{array}{l}\text { Desa / } \\
\text { Kelurahan }\end{array}$ & $\begin{array}{l}\text { Nama } \\
\text { Kelompok }\end{array}$ & $\begin{array}{l}\text { Jumlah Peserta } \\
\text { Program(KK) }\end{array}$ & $\begin{array}{l}\text { Jumlah } \\
\text { Sampel }\end{array}$ \\
\hline 1 & Tondano Timur & Kel. Liningaan & Mawar & 31 & 10 \\
2 & Tondano Utara & Kel. Sumalangka & Samerot & 30 & 10 \\
& & Ds.Tonsea Lama & Hortensia & 33 & 10 \\
3 & Eris & Ds. Touliang Oki & Tulip & 33 & 11 \\
4 & Kakas Barat & Desa Touliang & Ester & 35 & 12 \\
5 & Langowan Timur & Desa Waleure & Sanseviera & 35 & 12 \\
6 & Langowan Selatan & Desa Winebetan & Anggrek & 30 & 10 \\
7 & Langowan Utara & Desa Tempang II & Wintooran & 35 & 12 \\
8 & Kawangkoan & Ds. Kanonang III & Teluwan & 34 & 11 \\
9 & Tombulu & Desa Koka & Betlehem & 35 & 12 \\
10 & Tompaso & Desa Kamanga & Kamanga & 30 & 10 \\
11 & Kawangkoan Utara & Kiawa I & Tanjung & 30 & 10 \\
12 & Kawangkoan Barat & Kayuuwi I & Kemiri & 30 & 10 \\
\hline & Jumlah & & Sowotan & 321 & 140 \\
\hline
\end{tabular}

Besarnya jumlah sampel yang diambil dalam penelitian ditentukan dengan menggunakan teknik proporsional persentasi $30 \%$ dari populasi. Hasil perhitungan jumlah sampel diperoleh sebanyak 140 orang responden. Jumlah responden ini diperoleh dari perhitungan jumlah total rumah tangga (KK) kota dan kabupaten terpilih (Tabel 1).

Responden dipilih secara acak dengan metode simple random sampling, artinya setiap perempuan dalam kelompok memiliki kesempatan yang sama terpilih sebagai responden. Metode simple random sampling dilakukan pada tingkat desa/kelurahan.

Data sekunder diperoleh dari data hasil-hasil penelitian yang sudah ada, kajian pustaka yang relevan dengan aksesibilitas perempuan terhadap informasi pemanfaatan pekarangan mendukung diversifikasi pangan (dokumentasi buku, internet, media massa, serta sumber lainnya), serta data yang sudah ada di instansi pemerintah.

Instrumen yang digunakan dalam penelitian berupa kuesioner. Kuesioner tertutup dibuat berdasarkan kuesioner disediakan beberapa alternatif jawaban yang dapat dipilih responden sesuai dengan pengertian, penilaian, perasaan, dan kegiatan yang dialaminya.

Data dieksplorasi untuk melihat bagaimana karakteristik data, diamati secara deskriptif dengan tahapan: data indikator dari peubah aksesibilitas informasi ditabulasi dalam bentuk tabel frekuensi. Data yang diperoleh dianalisis dengan menggunakan analisis deskriptif.

Aksesibilitas terhadap informasi pemanfaatan pekarangan dan pengolahan pangan bersumber dari pekarangan dalam penelitian adalah ketepatan dan kecepatan yang dilakukan oleh perempuan dalam mencari dan memperoleh berbagai informasi/inovasi dari sumber informasi tentang usaha pemanfaatan pekarangan dan pengolahan pangan bersumber dari pekarangan. Analisis faktor aksesibilitas terhadap informasi pemanfaatan pekarangan dan pengolahan hasil pangan dalam penelitian ini mencakup: (1) tingkat ketersediaan informasi di lapangan terkait 
dengan informasi pemanfaatan pekarangan dan pengolahan pangan, yakni kuantitas/jumlah pesan yang mendukung kegiatan pemanfaatan pekarangan dan pengolahan pangan yang dibutuhkan oleh membutuhkan informasi yang akhirnya petani bisa mengakses informasi dimana saja, kapan saja, oleh siapa saja dan informasi menyebar dengan merata. Menurut (Matindas, 2011) pemanfaatan informasi

Tabel 2.Indikator, definisi operasional dan parameter pengukuran terhadap faktor aksesibilitas terhadap informasi pemanfaatan pekarangan

\begin{tabular}{|c|c|c|c|c|}
\hline No & Indikator & Definisi Operasional & Parameter Pengukuran & $\begin{array}{l}\text { Kategori } \\
\text { Pengukuran } \\
\end{array}$ \\
\hline 1 & $\begin{array}{l}\text { Ketersediaan } \\
\text { informasi }\end{array}$ & $\begin{array}{l}\text { Kuantitas pesan yang } \\
\text { mendukung kegiatan } \\
\text { pemanfaatan pekarangan dan } \\
\text { pengolahan pangan yang } \\
\text { dibutuhkan oleh perempuan } \\
\text { pemanfaat pekarangan }\end{array}$ & $\begin{array}{l}\text { Diukur berdasarkan: } \\
\text { Ketersediaan(jumlah informasi), } \\
\text { dan kemudahan dalam } \\
\text { memperoleh informasi }\end{array}$ & $\begin{array}{l}\text { Tidak tersedia } \\
\text { Kurangtersedia } \\
\text { Tersedia } \\
\text { Sangattersedia }\end{array}$ \\
\hline 2 & $\begin{array}{l}\text { Kesesuaian } \\
\text { informasi yang } \\
\text { diterima }\end{array}$ & $\begin{array}{l}\text { Kua litas pesan yang } \\
\text { diperoleh sesuai dengan yang } \\
\text { dibutuhkan }\end{array}$ & $\begin{array}{l}\text { Diukur berdasarkan: } \\
\text { kesesuaian informasi dengan } \\
\text { tujuan, kebutuhan, kesesuaian } \\
\text { kemanfaatan informasi, } \\
\text { Kesesuaian penerapan Informasi } \\
\text { yang diperoleh, kesesuaian } \\
\text { informasi dengan sarana } \\
\text { produksi }\end{array}$ & $\begin{array}{l}\text { Tidak sesuai } \\
\text { Kurang sesuai } \\
\text { Sesuai } \\
\text { SangatSesuai }\end{array}$ \\
\hline 3 & $\begin{array}{l}\text { Kredibilitas } \\
\text { orang/pemberi } \\
\text { informasi }\end{array}$ & $\begin{array}{l}\text { Kua litas, kapabilitas, a tau } \\
\text { kekuatan yang dimiliki oleh } \\
\text { petugas pesan untuk } \\
\text { menimbulkan kepercayaan }\end{array}$ & $\begin{array}{l}\text { Diukur berdasarkan: } \\
\text { tingkat pengetahuan terhadap } \\
\text { informasi, kemudahan } \\
\text { pela yanan, sikapempati, } \\
\text { kemampuan berkomunikasi, } \\
\text { kemampuan dalam } \\
\text { mempraktikkan apa yang } \\
\text { disuluhkan }\end{array}$ & $\begin{array}{l}\text { 1. Rendah } \\
\text { 2. Sedang } \\
\text { 3. Tinggi } \\
\text { 4. Sangat tinggi }\end{array}$ \\
\hline
\end{tabular}

perempuan pemanfaat pekarangan; (2) kesesuaian informasi yang diterima oleh responden yakni kualitas pesan yang diperoleh sesuai dengan yang dibutuhkan; (3) serta, kredibilitas pemberi informasi, kualitas, kapabilitas, atau kekuatan yang dimiliki oleh petugas pesan untuk menimbulkan kepercay aan (Tabel 2).

\section{HASIL DAN PEMBAHASAN}

\section{Ketersediaan informasi}

Pesatnya perkembangan teknologi komunikasi dewasa ini berdampak pada banyaknya media komunikasi yang dapat digunakan dalam mendiseminasikan informasi pertanian. Kegiatan pertanian yang petani lakukan, sangatlah adalah efek dari informasi yang sudah diterima, diakses dan dikontrol oleh petani.

Ketersediaan informasi tentang pemanfaatan pekarangan sangat dibutuhkan oleh responden untuk mendukung kegiatan usahatani di pekarangan. Kemudahan akses terhadap informasi diharapkan dapat mendorong petani untuk terus mencari informasi dalam mendukung kegiatan usaha taninya. Informasi dapat diakses dari berbagai sumbersumber informasi.

Sumber informasi sangat berpengaruh terhadap proses adopsi inovasi (Soekartawi, 2005). Sumber informasi dapat berasal dari media massa (televisi, surat kabar dan lain-lain) dan saluran interpersonal seperti teman, petugas penyuluh pertanian, pedagang, atau berasal dari informasi lainnya. 
(Wardhani, 1994) mengemukakan bahwa sumber informasi digunakan untuk tujuan yang berbedabeda; media massa untuk menyebarkan fakta kepada petani secara cepat. Selanjutnya dikatakan pula bahwa, sumber informasi adalah partisipan atau lembaga yang dapat menghasilkan informasi sebagai pesan dalam suatu proses komunikasi.

Tabel 3 menunjukkan, aksesibilitas terhadap ketersediaan dan kemudahan dalam memperoleh informasi tentang pemanfaatan pekarangan dan pengolahan pangan berada dalam kategori tersedia. Namun jumlah informasi yang ada dan jenis informasi yang dibutuhkan hanya sedikit/terbatas. Informasi yang tersedia di lapangan sebatas teknologi budidaya secara umum. Informasi pengolahan hasil pangan bersumber dari pekarangan, serta informasi pasar, masih kurang tersedia di lapangan. (Andriaty, Sankarto, \& Setyorini, 2011) menyatakan, ketersediaan sumber informasi di dekat petani akan berpengaruh terhadap intensitas akses petani terhadap informasi yang dibutuhkan untuk mendukung kegiatan usaha taninya.

(Elian, Lubis, \& Rangkuti, 2014) menyatakan, beberapa informasi penting yang dibutuhkan oleh petani yang penting bagi pertumbuhan dan perkembangan pertanian, antara lain informasi pasar, teknik terbaru dan teknologi, program pembangunan pedesaan dan subsidi, peramalan cuaca, teknologi pasca panen, berita pertanian umum, informasi tentang asuransi/klaim pengolahan, harga input dan ketersediaan input, peringatan dini dan manajemen penyakit dan hama, uji tanah dan informasi pengambilan contoh tanah. Hasil penelitian (Mulyandari, 2011) menemukan, hasil penelitian pertanian telah dihimpun dan dipublikasikan secara umum kepada masyarakat dengan berbagai media, namun informasi hasil penelitian pertanian tersebut pada kenyataannya belum mencapai sasaran utamanya, yaitu para petani.

(Manoppo, Amanah, Asngari, \& Tjitropranoto, 2017; Manoppo, Amanah, Asngari, \& Tjitropranoto, 2018) menyatakan bahwa, ketersediaan informasi yang diterima oleh perempuan peserta program KRPL dan P2KP berhubungan positif sangat nyata dengan persepsi perempuan terhadap fungsi pekarangan, serta berhubungan nyata positif dengan kompetensi teknis dan kompetensi sosial perempuan dalam melakukan kegiatan pemanfaatan pekarangan. Hal ini mengindikasikan, bahwa semakin banyak ketersediaan informasi teknologi tentang pemanfaatan pekarangan maka semakin tinggi pula persepsi responden terhadap pemanfaatan pekarangan yang berdampak pada peningkatan kompetensi perempuan dalam memanfaatkan pekarangan sebagai sumber pangan lokal. Selanjutnya dikatakan pula, bahwa ketersediaan sumber informasi di dekat responden akan berpengaruh terhadap intensitas akses responden terhadap informasi yang dibutuhkan untuk mendukung kegiatan usaha pekarangannya. Sejalan dengan penelitian (Bulu, Hariado, Herianto, \& Mudiyono, 2008) menyatakan bahwa, ketersediaan informasi sesuai jenis, jumlah, kualitas, dan tepat waktu saat dibutuhkan petani mampu meningkatkan adopsi inovasi teknologi.

Teknologi informasi dan komunikasi memiliki peranan penting dalam mewujudkan pertanian yang modern secara tepat waktu. Pada saat ini penguasaan terhadap teknologi informasi semakin menguat. Teknologi informasi diyakini sebagai alat pengubah untuk memperoleh kemudahan dalam aktivitas kehidupan sehari-hari dan selanjutnya memperoleh manfaat yang sangat banyak dari teknologi informasi. Perempuan pemanfaat pekarangan perlu memanfaatkan teknologi-teknologi informasi tersebut sehingga mereka tidak ketinggalan informasi, dan dapat mengembangkan usaha pemanfaatan pekarangan secara berkelanjutan bukan saja sebagai kebutuhan subsisten tetapi menjadi cabang usahatani yang menguntungkan (komersial).

Informasi yang didapatkan dapat menjadi acuan pengembangan dalam usaha pemanfaatan pekarangan maupun pengolahan hasil pasca panen bersumber dari pekarangan. Keterlibatan dari penyedia informasi tentu sangat penting. Perguruan tinggi, lembaga penelitian di bidang pertanian, pemerintah baik pusat maupun daerah, tokoh-tokoh masyarakat serta lembaga swadaya masyarakat harus secara proaktif menyediakan layanan-layanan 
informasi baik melalui ceramah, diskusi, media cetak berupa brosur dan leaflet serta memanfaatkan jaringan komunikasi, termasuk melalui internet yang saat ini cukup mudah dan terjangkau dari sisi penyedia informasi.

(Andriaty, Sankarto, \& Setyorini, 2011) mengatakan, ketersediaan kelembagaan dan sarana akses informasi yang makin baik juga memungkinkan petani mencari dan memperoleh informasi yang bermanfaat bagi usaha taninya. Semakin tinggi tingkat ketersediaan kelembagaan komunikasi dan ketersediaan sarana akses informasi akan mendorong tingkat kekosmopolitan yang makin tinggi dan selanjutnya akan meningkatkan tingkat manfaat informasi yang diakses karena semakin beragam dan komprehensifnya informasi yang diperoleh dan sumber informasi yang diakses.

Teknologi informasi termasuk jaringan komunikasi melalui internet tersebut, memudahkan responden saat ini bisa dipahami sebagai sebuah kegagalan karena hampir tidak ada lagi informasi pertanian yang ditampilkan. Sedangkan ketika internet menginvasi, beragam informasi pertanian bisa dengan mudah ditemukan, bahkan petani bisa berkelompok berdasarkan preferensinya dalam dunia virtual. Selain itu, juga masih ada banyak perubahan lain di sektor sosio kultural yang menimpa petani dan penyuluh.

Dari beberapa media yang dapat diakses menurut responden, media cetak (majalah dan tabloid) merupakan sarana yang paling mereka minati dalam memperoleh informasi mengenai pemanfaatan pekarangan, karena media cetak dapat dibaca ulang atau disimpan, sehingga memudahkan responden dalam memperoleh informasi jika informasi tersebut sewaktu-waktu mereka butuhkan. Hal ini sejalan dengan pendapat (Andriyaty \& Setyorini, 2012), kelebihan media cetak dibanding media lainnya adalah dapat dibaca ulang, memudahkan pengguna

Tabel 3. Ketersediaan Informasi pemanfaatan pekarangan di Kabupaten Minahasa

\begin{tabular}{lllll}
\hline No. & Indikator & Kategori & Frekuensi & Persentasi (\%) \\
\hline 1. & Tingkat ketersediaan informasi & 1 = Tidak tersedia & 0 & 0,00 \\
& teknologitentang usaha pekarangan & 2 = Kurang tersedia & 48 & 34,28 \\
& & 3 = Tersedia & 88 & 62,86 \\
& & 4 = Sangat tersedia & 4 & 2,86 \\
2. & Jumlah informasiteknologitentang & 1 = Sangat sedikit $(<2)$ & 11 & 7,86 \\
& jenis-jenis usaha dipekarangan & 2 = Sedikit $(2-3)$ & 83 & 59,28 \\
& & 3 = Banyak $(4-5)$ & 44 & 31,43 \\
& & 4 = Sangat banyak $(>5)$ & 2 & 1,43 \\
3. & Akses (tingkat kemudahan)dalam & 1 = Sangat sulit & 2 & 1,43 \\
& memperoleh informasitentang & 2 = Sulit & 47 & 33,57 \\
& usaha pekarangan & 3 = Mudah & 88 & 62,86 \\
\hline
\end{tabular}

(Sumber: Data primer telah diolah, 2015)

memperoleh informasi yang mereka butuhkan. Dewasa ini, internet memberikan banyak kemudahan bagi pemberi informasi termasuk penyuluh, karena bisa mengatasi masalah ruang dan waktu. Hal ini berbanding terbalik ketika dahulu penyuluh masih memanfaatkan metode lama yang harus bertatap muka dan masih menggunakan media konvensional seperti televisi dan radio. Penggunaan media tersebut mencerna informasi, dan dapat disimpan. Lubis (Andriaty, Sankarto, \& Setyorini, 2011) menyatakan, televisi tidak saja berpotensi untuk menyampaikan informasi, tetapi juga dapat membentuk perilaku seseorang, baik ke arah positif maupun negatif.

(Ghazali, 2013) menyatakan bahwa, perempuan dan keluarganya percaya, berkebun di rumah menjadi penting berawal ketika mereka selesai menonton 
televisi dan membaca majalah tentang manfaat berkebun. Informasi lainnya mengenai pemanfaatan pekarangan dan pengolahan pangan bersumber dari pekarangan di Minahasa berasal dari internet (telepon genggam), namun karena tidak semua jaringan internet yang ada di lokasi penelitian stabil/memadai, menyebabkan aksesibilitas terhadap informasi tersebut terhambat. Di beberapa lokasi penyebarluasan informasi inovasi pertanian secara terprogram, tepat waktu, dan relevan dalam mendukung proses pengambilan keputusan petani dan penyuluh yang akan menentukan keberhasilan penyuluhan.

Hasil penelitian (Asmara \& Rahmah, 2010) tentang sumber informasi menunjukkan bahwa, semakin banyak sumber informasi yang dimiliki ibu rumah

Tabel 4. Kesesuaian informasi pemanfaatan pekarangan di Kabupaten Minahasa

\begin{tabular}{|c|c|c|c|c|}
\hline No. & Indikator & Kategori & Frekuensi & Persentasi $(\%)$ \\
\hline \multirow[t]{4}{*}{1.} & Tingkat kesesuaian informasi teknologi & 1 = Tidak sesuai & 1 & 0,71 \\
\hline & pemanfaatan pekarangan dengan & $2=$ Kurang sesuai & 6 & 4,29 \\
\hline & kebutuhan usaha pekarangan & $3=$ Sesuai & 106 & 75,71 \\
\hline & & $4=$ Sangat sesuai & 27 & 19,29 \\
\hline \multirow[t]{4}{*}{2.} & Intensitas penerapan informasi teknologi & $1=$ Tida $\mathrm{k}$ pernah & 0 & 0,00 \\
\hline & pemanfaatan pekarangan yang diperoleh & $2=$ Kadang-kadang & 29 & 20,71 \\
\hline & da lam usaha pemanfaatan pekarangan & $3=$ Sering & 109 & 77,86 \\
\hline & & $4=$ Selalu & 2 & 1,43 \\
\hline \multirow[t]{4}{*}{3.} & Tingkat kesesuaian penerapan/a plikasi & $1=$ Tida $\mathrm{k}$ sesuai & 1 & 0,71 \\
\hline & informasi pemanfaatan pekarangan yang & $2=$ Kurang sesuai & 23 & 16,43 \\
\hline & diperoleh & $3=$ Sesuai & 114 & 81,43 \\
\hline & & $4=$ Sangat sesuai & 2 & 1,43 \\
\hline \multirow[t]{4}{*}{4.} & Kesesua ian informasi teknologiyang & $1=$ Tida $\mathrm{k}$ sesuai & 1 & 0,71 \\
\hline & diperoleh dengan tujuan pemanfaatan & $2=$ Kurang sesuai & 45 & 32,14 \\
\hline & peka rangan yang ingin dica pai & $3=$ Sesuai & 92 & 65,71 \\
\hline & & $4=$ Sangat sesuai & 2 & 1,43 \\
\hline \multirow[t]{4}{*}{5.} & Penera pan informasi teknologi yang & $1=$ Tida $\mathrm{k}$ sesuai & 1 & 0,71 \\
\hline & diperoleh sesuai dengan ketersediaan & $2=$ Kurang sesuai & 26 & 18,57 \\
\hline & sara na produksi (alat dan bahan) yang ada & $3=$ Sesuai & 110 & 78,57 \\
\hline & & $4=$ Sangat sesuai & 3 & 2,14 \\
\hline
\end{tabular}

Sumber: Data nrimer vang telah diolah. 2015

penelitian yang jaringan internetnya lancar, responden dengan mudah mengakses informasi pemanfaatan pekarangan dan pengolahan pangan bersumber dari pekarangan yang mereka butuhkan. Jaringan media sosial seperti facebook cukup membantu responden dalam memperoleh informasi yang mereka butuhkan terlebih informasi mengenai pengolahan pangan, namun karena keterbatasan cara penggunaan jaringan ini, responden mengalami kesulitan jika sewaktu-waktu membutuhkan informasi tersebut.

(Sharma, 2006) dan (Mardikanto, 1993), pengimplementasian teknologi informasi dan komunikasi seperti cyber extension di sektor pertanian merupakan salah satu mekanisme pengembangan model pemberdayaan dan tangga, maka akan semakin tinggi pula pemahamannya terhadap gizi. Oleh karena itu, upaya penyampaian informasi teknologi, khususnya bidang pemanfaatan pekarangan, hendaknya dikemas secara terarah, terencana dan periodik kepada kelompok perempuan tani pemanfaat pekarangan sehingga dapat mempercepat proses meningkatnya pengetahuan, kesadaran memilih jenis komoditas usaha pekarangan dan melakukan kegiatan pemanfaatan pekarangan.

\section{Kesesuaian Informasi}

Penerapan informasi inovasi teknologi juga ditentukan oleh sifat inovasi itu sendiri. Informasi inovasi teknologi yang diterima akan diterapkan pengguna, jika secara teknis mudah dilaksanakan, 
secara ekonomi menguntungkan, dan secara sosial budaya dapat diterima masyarakat. Untuk mengetahui tingkat kesesuaian informasi yang dibutuhkan responden, digunakan parameter: seberapa sering informasi yang diperoleh tersebut diterapkan, bagaimana nilai kemanfaatan dari informasi yang diterima oleh responden, apakah penerapan informasi teknologi yang diperoleh sesuai dengan ketersediaan sarana serta, apakah informasi yang diperoleh sejalan dengan tujuan yang ingin responden capai.

Kesesuaian informasi yang diterima mengenai pemanfaatan pekarangan dan pengolahan pangan berdasarkan indikator penilaian (Tabel 4) berkategori sesuai. Meskipun secara rata-rata tingkat kesesuaian informasi dikategorikan sesuai, namun informasi teknologi yang diperoleh dari petugas lapangan PPL dan petugas lapang lainnya (Dinas Pertanian, BKP, dan BPTP), dianggap belum semuanya sesuai. (Nwankwo, Peters, \& Bokelmann, 2010) menyatakan, petani mencari informasi khususnya informasi yang relevan dari berbagai sumber untuk mengurangi risiko dan ketidakpastian sehingga diharapkan utilitas dari setiap inovasi teknologi yang diberikan dapat dimaksimalkan. Informasi mengenai pemanfaatan pekarangan dan pengolahan pangan yang diperoleh melalui media cetak (majalah dan tabloid), menurut mereka informasi tersebut sesuai dengan yang dibutuhkan, dan dapat diterapkan. Melalui kesesuaian informasi yang diperoleh, perempuan dapat memilih jenis komoditas usaha pekarangan yang sesuai untuk dikembangkan di lahan pekarangan miliknya, serta jenis komoditas yang mempunyai nilai kemanfaatan, terutama bermanfaat bagi pemenuhan pangan dan gizi keluarga, serta mempunyai nilai ekonomi jika dijual. Semakin sesuainya informasi tentang pemanfaatan pekarangan dan pengolahan pangan bersumber dari pekarangan, yang diterima oleh responden di lokasi penelitian, maka akan meningkatkan: kemampuan responden dalam mengusahakan kontinuitas bahan pangan di pekarangan, meningkatkan kontribusi pekarangan terhadap pangan, serta meningkatkan kontribusi pekarangan terhadap pendapatan.

(Manoppo, Amanah, Asngari, \& Tjitropranoto, 2017) menyatakan bahwa, kesesuaian informasi yang diterima oleh perempuan pemanfaat pekarangan berhubungan nyata positif dengan persepsi perempuan tentang pemanfaatan pekarangan mendukung diversifikasi pangan. Hal ini mengindikasikan bahwa, tingkat kesesuaian informasi sangat menentukan persepsi dari responden. Semakin sesuainya informasi pemanfaatan pekarangan dan pengolahan pangan bersumber dari pekarangan yang diterima oleh responden cenderung akan diikuti oleh meningkatnya persepsi positif terhadap pemanfaatan pekarangan mendukung diversifikasi pangan. Sebagian besar responden menyatakan bahwa informasi yang mereka terima mengenai informasi tentang pemanfaatan pekarangan, diversifikasi pangan dan informasi tentang makanan sehat, hampir semuanya sesuai dengan yang mereka butuhkan. Menurut penilaian mereka, optimalisasi lahan pekarangan sebagai sumber bahan makanan bagi keluarga dapat mereka lakukan dengan mudah, apabila informasi yang diberikan secara benar dan jelas.

(Manoppo, Amanah, Asngari, \& Tjitropranoto, 2018) menyatakan, kesesuaian informasi berhubungan sangat nyata positif dengan kompetensi teknis, kompetensi manajerial dan kompetensi sosial perempuan dalam usaha pemanfaatan pekarangan. Informasi yang telah diperoleh responden akan lebih berdaya guna bila informasi tersebut sesuai dengan kebutuhan mereka. Kebutuhan terhadap informasi yang sesuai dengan teknologi budidaya pekarangan termasuk teknologi budidaya pekarangan yang sesuai dengan luas pekarangan yang mereka miliki, harga komoditas usaha pekarangan, mutu hasil usaha pekarangan dan peluang pasar, pengolahan pangan sangat diharapkan oleh responden dalam mengembangkan usaha pekarangannya. Semakin informasi itu berkaitan erat dengan permasalahan yang sedang dihadapi dan semakin informasi 
tersebut sesuai pandangan responden dengan kondisi yang ada maka, akan semakin meningkatkan kompetensi teknis, manajerial dan sosial yang dimiliki oleh responden. (Prawiranagara, 2016) menyatakan bahwa, terdapat pengaruh karakteristik informasi terhadap kapabilitas petani mengelola inovasi. Semakin berkualitas informasi yang diperoleh petani, kemudian informasi tersebut dijadikan dasar pengelolaan usahatani, maka dapat meningkatkan kemampuan inovasi untuk meraih kesuksesan usaha.

\section{Kredibilitas pemberi informasi}

Kredibilitas merupakan kualitas, kapabilitas, atau kekuatan untuk menimbulkan kepercayaan. Informasi tentang pemanfaatan pekarangan dan pengolahan hasil pangan bersumber dari pekarangan (pangan lokal) diperoleh dari petugas lapangan (PPL, Badan Ketahanan Pangan serta BPTP), aparat desa, kelompok PKK, media cetak dan media elektronik (sarana komunikasi seperti: telepon rumah, telepon genggam, komputer, siaran radio/televisi, dan warung internet). Sumber yang memberikan informasi harus kredibel artinya dapat dipercaya dan mengetahui dengan pasti apa yang sedang terjadi atau berlaku di masyarakat. Sumber yang kredibel dapat dikatakan sebagai sumber yang memberikan pernyataan sebagaimana adanya, karena tujuan sumber untuk menjelaskan atau memberikan informasi yang diketahui, dimengerti dan dipahami. Sumber yang cakap atau kompeten adalah sumber yang berkualitas dan berkemampuan. Dalam hal ini pemberi informasi harus mengetahui dan memaparkan ide-ide atau gagasan yang inovatif dengan bukti yang nyata dan benar, melakukan segala sesuatu dengan penuh perhitungan dan perencanaan yang matang, mampu memberikan pelayanan, mampu berkomunikasi dengan baik serta mampu mempraktikkan apa yang disuluhkan.

Tabel 5 menunjukkan bahwa, kredibilitas pemberi informasi tentang usaha pemanfaatan pekarangan di Kabupaten Minahasa, berdasarkan lima indikator penilaian yakni: tingkat penguasaan pengetahuan terhadap informasi; kemudahan dalam memberikan pelayanan; sikap empati dari pemberi informasi; kemampuan berkomunikasi pemberi informasi; serta kemampuan dalam mempraktikkan apa yang disuluhkan, semuanya masih berada dalam kategori kurang kredibel. Ini disebabkan antara lain karena, pemberi informasi (petugas pendamping P2KP dan MKRPL) hanya sekedar menjalankan tugas atau memberi instruksi sesuai dengan petunjuk teknis pelaksanaan program MKRPL dan P2KP, serta informasi yang diberikan belum semuanya sesuai dengan keinginan dan kebutuhan perempuan dan kelompoknya. Menurut (Sumardjo, 1999), filosofi dan prinsip-prinsip penyuluhan dalam arti yang sebenarnya adalah partisipatif, dialogis, konvergen, dan demokratis, sehingga memberdayakan, bukan praktik-praktik penyuluhan yang bersifat top down, linier serta bertentangan dengan filosofi pembangunan manusia. Menurut (Asngari, 2011) penyuluhan adalah kegiatan mendidik, bukan memaksa terjadinya perubahan perilaku SDM-klien. Karena itu, agen perubahan perlu menguasai ilmu mendidik, baik pada pedagogik maupun andragogik.

(Slamet, 2003) mengungkapkan bahwa pelayanan jasa informasi bagi petani merupakan salah satu prinsip dalam paradigma baru penyuluhan pertanian. Oleh sebab itu, untuk meningkatkan pengetahuan petani penyuluhan pertanian harus mampu menyediakan dan memberikan segala informasi yang dibutuhkan petani. Sumber informasi Interpersonal merupakan media yang strategis untuk menyampaikan informasi, peran agen pembaharu seperti penyuluh sangat diperlukan untuk memberikan informasi tentang teknologi pemanfaatan pekarangan.

Sebanyak 57,14\% responden menilai, tingkat penguasaan pengetahuan pemberi informasi tentang teknologi pemanfaatan pekarangan berada dalam kategori kurang menguasai. Pemberi informasi tentang usaha pemanfaatan pekarangan di Kabupaten Minahasa Kabupaten Minahasa adalah petugas dari Badan Ketahanan Pangan dan penyuluh pertanian lapangan. Petugas dari Badan Ketahanan Pangan hanya sekedar memberikan bantuan sarana produksi (bibit, pupuk, polibag) tanpa pendampingan teknologi pemanfaatan pekarangan sebagai sumber bahan pangan pada petani dalam melaksanakan 
program P2KP. Demikian halnya dengan penyuluh pertanian lapangan. Tingkat pengetahuan penyuluh pertanian terhadap teknologi pemanfaatan pekarangan masih terbatas. Penyuluh pertanian lapangan lebih menguasai teknologi budidaya tanaman pangan secara umum (padi, jagung dan kedelai). (Amanah, Hastuti, \& Basuno, 2008) menyatakan bahwa, antara penyuluh dengan petani dan kemampuan penyuluh sangat berhubungan dengan kelanjutan program dan hal ini perlu didukung oleh kebijakan penyuluhan di masingmasing lokasi. Para penyuluh yang berinteraksi intensif dengan masyarakat, maka tingkat kepercayaan petani semakin tinggi, sehingga program akan lebih mudah dilaksanakan. (Anwas, 2011) menyatakan bahwa, untuk meningkatkan kemampuan dalam pengelolaan komunikasi inovasi, penyuluh harus meningkatkan kemampuannya dalam mencari informasi inovasi melalui berbagai sumber informasi, memahami inovasi yang dibutuhkan petani, serta mengkomunikasikannya dengan bahasa yang mudah dipahami dan dilakukan secara dialogis.

Belajar adalah tuntutan profesi bagi penyuluh pertanian. Selain itu, seorang penyuluh pertanian harus terus menerus menambah input berupa pengetahuan akan ilmu-ilmu penyuluhan terkini lewat pelatihan atau seminar-seminar, karya tulis atau karya ilmiah dan buku-buku yang dapat meningkatkan kompetensi penyuluh pertanian itu sendiri. Belajar tidak hanya melalui pendidikan formal atau pelatihan saja, tetapi banyak media lainnya yang dapat dimanfaatkan untuk meningkatkan kemampuan penyuluh, termasuk media massa dan media lingkungan. Proses pembelajaran yang berlangsung harus mengacu pada pembelajaran partisipatif di mana posisi pemberi informasi termasuk penyuluh, perempuan dan kelompoknya adalah setara. Sama-sama belajar dari masalah yang dihadapi. Pemberi informasi dan penyuluh berperan sebagai sumber informasi. (Yumi, 2011)menyatakan bahwa, kompetensi penyuluh mempengaruhi intensitas belajar petani. Selanjutnya ditambahkan pula bahwa, aspek kompetensi penyuluh yang berpengaruh terhadap intensitas belajar adalah kemampuan penyuluh dalam: menganalisa permasalahan, meningkatkan kapasitas petani dan mengembangkan wawasan teknis petani. Untuk itu, penyuluh harus memiliki kemampuan yang tinggi dalam menggunakan media belajar dan strategi belajar yang bisa membuat perempuan dan kelompoknya dapat berpartisipasi aktif. Penyuluh dan perempuan pemanfaat pekarangan bersama-sama dengan anggota kelompok lainnya menetapkan waktu pelaksanaan penyuluhan, disesuaikan dengan kebutuhan waktu mereka, sehingga kehadiran perempuan pemanfaat pekarangan pada setiap kegiatan penyuluhan pemanfaatan pekarangan dan pengelolaan sumber pangan dan gizi dapat meningkat.

Kemudahan dalam memberikan pelayanan, sebanyak 47,86\% responden menilai petugas kurang mudah dalam memberikan pelayanan. Informasi yang diberikan oleh petugas adalah dalam bentuk pertemuan kelompok serta sekolah lapang. Intensitas pertemuan kelompok dan sekolah lapang yang dilaksanakan sangat terbatas jumlahnya. Kelembagaan penyuluhan dan Badan Ketahanan Pangan adalah kelembagaan formal yang merupakan salah satu sumber informasi utama bagi responden dalam memperoleh informasi pemanfaatan pekarangan sebagai sumber bahan pangan keluarga. Menurut (Tologbonse, Fashola, \& Obadiah, 2008) ketersediaan media personal seperti pertemuan sangat penting karena media tersebut paling disukai petani sebagai sarana untuk memperoleh informasi pertanian. (Andriaty \& Setyorini, 2012) mengatakan, dengan mengikuti penyuluhan, petani dapat memecahkan masalah yang berkaitan dengan usaha tani (98\%), menambah wawasan mengenai teknologi pertanian (98\%), maupun meningkatkan keterampilan $(97 \%)$.

Sikap empati dari pemberi informasi dinilai kurang empati (78\%). Pemberi informasi haruslah memiliki kaitan erat dengan perempuan dan kelompoknya, tertarik dengan permasalahan atau persoalan yang 
ada, mau berbagi pengetahuan dan ide, serta mau bekerjasama dengan perempuan dan kelompoknya. Pemberi informasi perlu memiliki kemampuan mengembangkan kelompok perempuan pemanfaat pekarangan, yaitu: menumbuhkan kesadaran perempuan terhadap manfaat berkelompok sehingga mereka berinisiatif untuk berkelompok, mengembangkan dinamika kelompok yang telah ada (memperjelas tujuan, struktur, dan pengelolaan kelompok perempuan pemanfaat pekarangan), agar anggota memperoleh manfaat berkelompok. Pemberi informasi juga harus membangun kegiatan penyuluhan yang difokuskan pada peningkatan pengetahuan, sikap mental, dan keterampilan budidaya pekarangan yang berwawasan agribisnis bagi perempuan dan kelompoknya, khususnya dalam hal: perencanaan usahatani lahan pekarangan yang menguntungkan, meraih nilai tambah usaha pekarangan, penerapan usaha pekarangan secara berkelanjutan, serta pelaksanaan kerjasama antar perempuan maupun pihak terkait lainnya. Begitu pula kesadaran pemberi informasi perlu ditingkatkan untuk terus belajar dalam meningkatkan kemampuannya sesuai tuntutan masyarakat, terutama dalam aspek pedoman dan petunjuk pelaksanaan usaha pemanfaatan pekarangan secara terpadu.

Penyuluh diperlukan sebagai komunikator yang baik, pembicara dan kemampuan mendorong pemimpin lokal untuk mengambil peran aktif dalam pembangunan pertanian. Kemampuan berkomunikasi pemberi informasi, dan kemampuan dalam mempraktikkan apa yang disuluhkan juga dinilai kurang mampu. Kegiatan penyuluhan tentang pemanfaatan pekarangan dilakukan di Kabupaten Minahasa yaitu dengan menggunakan dua pendekatan yakni: pendekatan perorangan dengan mengunjungi perempuan pemanfaat pekarangan dari rumah ke rumah untuk mengetahui permasalahan yang mereka hadapi (jarang dilakukan dan kunjungan dilakukan hanya pada orang-orang tertentu) serta, pendekatan kelompok (pertemuan kelompok dan sekolah lapangan).

Penggunaan metode yang sesuai dengan kebutuhan sasaran penyuluhan berperan dalam menunjang keberhasilan program penyuluhan. Sebaik apapun materi penyuluhan yang disampaikan tidak akan mampu mengubah perilaku sasaran yang diinginkan bila metode penyuluhan yang digunakan kurang tepat. (Manoppo, Amanah, Asngari, \& Tjitropranoto, 2017) menyatakan, metode penyuluhan pemanfaatan pekarangan dan pengolahan pangan hasil dari pekarangan yang dilaksanakan di Minahasa dan Bitung berkategori kurang sesuai. Diharapkan dengan pelaksanaan sekolah lapangan bukan hanya meningkatkan produksi usaha lahan pekarangan saja, namun juga memberikan efek jangka panjang terhadap perubahan perilaku perempuan dalam memanfaatkan pekarangan yang lebih baik, sehingga pemberdayaan sumberdaya perempuan baik aspek kesejahteraan maupun peningkatan kompetensi dapat tercapai. Kunjungan ke lokasi atau ke lahan pekarangan milik anggota, seharusnya tetap dilakukan secara berkala, sehingga kendala dan masalah pemanfaatan pekarangan yang dihadapi oleh perempuan pemanfaat pekarangan dapat diatasi. Selain itu, komunikasi yang lebih akrab antara anggota dan petugas lapangan lebih tercipta dengan baik.

Dilihat dari sisi konsep dan asumsi yang mendasari pendekatan sekolah lapangan, maka perlu dilakukan beberapa perbaikan dalam perencanaan dan pelaksanaan kegiatan sekolah lapangan pemanfaatan pekarangan. Aspek kunci yang menjadikan pelaksanaan sekolah lapangan sebagai wahana dalam peningkatan kemampuan perempuan dalam pemanfaatan pekarangan, dapat didekati dengan beberapa cara sebagai berikut: (1) penjelasan konsep pemanfaatan pekarangan, lebih ditekankan kepada sisi teknis, dengan pertimbangan aspek kearifan dan sumberdaya lokal yang ada termasuk sumberdaya perempuan pemanfaat pekarangan. Artinya, dalam menjelaskan konsep pemanfaatan pekarangan secara terpadu, harus lebih disederhanakan dan memberikan kesan mudah dilaksanakan, sehingga tidak menimbulkan hambatan psikologis yang tinggi, yang pada akhirnya akan mengurangi tingkat kesadaran dan minat perempuan berserta kelompoknya terhadap teknologi pemanfaatan pekarangan; (2) dalam pelaksanaan kegiatan sekolah lapangan, tujuan membangun kesadaran perempuan dan kelompoknya 
untuk mau dan mampu memanfaatkan pekarangan yang mereka miliki sebagai sumber keanekaragam an pangan yang aman dan bergizi, tersebut bersifat evolutif dan membutuhkan waktu, sehingga memerlukan proses seleksi dalam menentukan tujuan kegiatan penyuluhan, atau dengan kata lain perlu diingat bahwa proses penyerapan teknologi pemanfaatan pekarangan secara terpadu harus dilakukan tahap demi tahap; (3) menciptakan kebutuhan terhadap perubahan perilaku perempuan dan kelompok perempuan pemanfaat pekarangan, kontinu, bukan hanya pada kelompok tetapi juga dilakukan kunjungan pada lahan pekarangan anggota kelompok. Hal ini untuk menjaga jika terjadi penurunan motivasi perempuan manakala menjumpai kesulitan dan hambatan. Kegiatan pemanfaatan pekarangan sebagai sumber pangan tetap membutuhkan pengawalan dan pendampingan yang intensif, meskipun bertanam di pekarangan bukanlah hal yang baru, namun tanpa dilakukan pendampingan secara intensif akan sulit merubah perilaku perempuan dan keluarganya untuk

Tabel 5. Kredibilitas pemberi informasi pemanfaatan pekarangan di Kabupaten Minahasa

\begin{tabular}{|c|c|c|c|c|}
\hline No. & Indikator & Kategori & Frekuensi & Persentasi $(\%)$ \\
\hline 1. & $\begin{array}{l}\text { Tingkat penguasaan pengetahuan } \\
\text { terha dap informasi }\end{array}$ & $\begin{array}{l}1=\text { Tidak menguasai } \\
2=\text { Kurang menguasai } \\
3=\text { Menguasai } \\
4=\text { Sangat menguasai }\end{array}$ & $\begin{array}{l}23 \\
80 \\
34 \\
3\end{array}$ & $\begin{array}{l}16,43 \\
57,14 \\
24,29 \\
2,14\end{array}$ \\
\hline 2. & $\begin{array}{l}\text { Kemudahan dalam memberikan } \\
\text { pelayanan }\end{array}$ & $\begin{array}{l}1=\text { Tidak mudah } \\
2=\text { Kurang mudah } \\
3=\text { Mudah } \\
4=\text { Sangat mudah }\end{array}$ & $\begin{array}{l}7 \\
67 \\
59 \\
7\end{array}$ & $\begin{array}{l}5,00 \\
47,86 \\
42,14 \\
5,00\end{array}$ \\
\hline 3. & Sika p empati daripemberi informasi & $\begin{array}{l}1=\text { Tidak empati } \\
2=\text { Kurang empati } \\
3=\text { Empati } \\
4=\text { Sangat empati }\end{array}$ & $\begin{array}{l}6 \\
78 \\
49 \\
7\end{array}$ & $\begin{array}{l}4,29 \\
55,71 \\
35,00 \\
5,00\end{array}$ \\
\hline 4. & $\begin{array}{l}\text { Kema mpuan berkomunikasi pemberi } \\
\text { informasi }\end{array}$ & $\begin{array}{l}1=\text { Sangat mampu } \\
2=\text { Kurang mampu } \\
3=\text { Mampu } \\
4=\text { Sangat mampu }\end{array}$ & $\begin{array}{l}6 \\
70 \\
59 \\
5\end{array}$ & $\begin{array}{l}4,29 \\
50,00 \\
42,14 \\
3,57\end{array}$ \\
\hline 5. & $\begin{array}{l}\text { Kema mpuan dalam mempraktikkan } \\
\text { a pa y ang disu luhkan }\end{array}$ & $\begin{array}{l}1=\text { Sangat mampu } \\
2=\text { Kurang mampu } \\
3=\text { Mampu } \\
4=\text { Sangat mampu }\end{array}$ & $\begin{array}{l}6 \\
70 \\
59 \\
5\end{array}$ & $\begin{array}{l}4,295 \\
50,00 \\
42,14 \\
3.57\end{array}$ \\
\hline
\end{tabular}

Sumber: Data primeryang telah diolah, 2015

dapat dilakukan dengan memberikan gambaran yang jelas dan gamblang mengenai fungsi pelaksanaan pemanfaatan pekarangan. Diharapkan dengan adanya nilai manfaat yang tinggi, akan memberikan dorongan atau motivasi secara internal terhadap diri perempuan dan kelompoknya. Aspek ini dapat diimbangi dengan dorongan motivasi ekstrinsik di antaranya dengan diberikannya bantuan sarana produksi dalam pelaksanaan kegiatan pemanfaatan pekarangan; (4) bimbingan (pendampingan) dan arahan senantiasa dilaksanakan secara berkala dan senantiasa memanfaatkan pekarangan sebagai sumber bahan pangan.

Kegiatan pendampingan/penyuluhan ini harus bersifat monitoring bukan hanya sekedar instruksi dan evaluasi akhir saja. Dengan adanya monitoring secara berkala, diharapkan potensi masalah dapat teratasi dengan segera, dan yang lebih penting dari kegiatan bimbingan ini adalah menciptakan hubungan komunikasi yang harmonis antara petug as lapangan (penyuluh dan instansi terkait termasuk BPTP) dengan perempuan beserta kelompok 
perempuan pemanfaat pekarangan. Diharapkan dengan pelaksanaan sekolah lapangan bukan hanya meningkatkan produksi usaha lahan pekarangan saja, namun juga memberikan efek jangka panjang terhadap perubahan perilaku dalam memanfaatkan pekarangan yang lebih baik, sehingga pemberdayaan sumberdaya perempuan baik dalam aspek kesejahteraan maupun peningkatan kompetensi dapat tercapai. Beberapa saran dari responden sebaiknya metode serta pendekatan penyuluhan yang digunakan, ditambah dengan kunjungan ke lokasi atau ke lahan pekarangan milik anggota, sehingga lebih tercipta komunikasi yang lebih akrab antara anggota dan petugas.Kegiatan penyuluhan merupakan sarana yang bersentuhan langsung dengan perempuan dan kelompok perempuan pemanfaat pekarangan untuk memperoleh informasi tentang usaha pemanfaatan pekarangan dan pengolahan hasil pangan bersumber dari pekarangan. Melalui kegiatan penyuluhan pemanfaatan pekarangan, dapat memperbaiki dan meningkatkan persepsi positif, pola pikir, dan tindakan yang dimiliki seseorang termasuk perempuan pemanfaat pekarangan dan kelompoknya. Meningkatnya persepsi perempuan melalui kegiatan penyuluhan, maka dapat berdampak, perempuan pemanfaat pekarangan dan kelompoknya akan tahu, mau dan mampu memanfaatkan pekarangan yang mereka miliki sebagai salah satu sumber pangan untuk keluarga. Oleh karena itu, intensitas penyuluhan harus ditingkatkan dan dikembangkan serta dilakukan secara teratur, terencana dan terarah. Semakin banyaknya/seringnya dilakukan penyuluhan tentang pemanfaatan pekarangan, maka akan meningkatkan kompetensi yang dimiliki oleh perempuan dan kelompoknya.

(Manoppo, Amanah, Asngari, \& Tjitropranoto, 2018) menyatakan, kredibilitas pemberi informasi berhubungan nyata $(\alpha=0,05)$ dengan kompetensi manajerial responden. Korelasi ini mengindikasikan, semakin kredibel pemberi informasi akan meningkatkan kompetensi manajerial perempuan pemanfaat pekarangan. Kompetensi manajerial dalam kegiatan pemanfaatan pekarangan adalah kemampuan perempuan dalam berkomunikasi, berinteraksi dan membangun hubungan serta jaringan dengan orang lain. Penyuluhan pertanian yang sebelumnya hanya berfokus pada kegiatan transfer teknologi bagi perempuan dan keluarganya kini memiliki cakupan lebih luas, yaitu mencakup keseluruhan proses pembelajaran bagi perempuan dan anggota kelompok sebagai pelaku utama dan pelaku usaha agar mereka mau dan mampu menolong dan mengorganisasikan dirinya dalam mengakses informasi pasar, teknologi, permodalan dan sumberdaya lainnya sebagai upaya meningkatkan produktivitas, efisiensi usaha, pendapatan dan kesejahteraannya serta meningkatkan kesadaran dalam mengoptimalisasi pekarangan yang mereka miliki sebagai sumber keanekaragaman pangan.

\section{UCAPAN TERIMA KASIH}

Artikel ini merupakan bagian dari hasil penelitian yang dibiayai oleh Badan Penelitian dan Pengembangan Pertanian. Penulis mengucapkan terima kasih pada Dr. Ir. Siti Amanah, MSc; Prof. Dr. Pang S. Asngari; dan Dr. Prabowo Tjitropranoto, yang telah banyak membantu, mengarahkan serta membimbing dalam penelitian dan penulisan karya tulis ilmian ini.

\section{KESIMPULAN}

Aksesibilitas terhadap ketersediaan informasi tentang pemanfaatan pekarangan dan pengolahan pangan di Kabupaten Minahasa berada dalam kategori tersedia. Namun, jumlah informasi yang ada dan jenis informasi yang dibutuhkan masih kurang tersedia. Informasi yang tersedia masih terbatas pada teknologi budidaya tanaman pangan secara umum.

Kesesuaian informasi mengenai pemanfaatan pekarangan dan pengolahan pangan yang diterima oleh perempuan peserta program KRPL dan P2KP berdasarkan indikator penilaian seberapa sering informasi yang diperoleh tersebut diterapkan, nilai kemanfaatan dari informasi yang diterima oleh responden, penerapan informasi teknologi yang diperoleh sesuai dengan ketersediaan sarana serta, informasi yang diperoleh sejalan dengan tujuan yang 
ingin responden capai, berkategori sesuai. Meskipun secara persentase tingkat kesesuaian informasi berada dalam kategori sesuai, namun informasi teknologi yang diperoleh dari petugas lapangan (PPL) dan petugas lapang lainnya (Dinas Pertanian, BKP, dan BPTP), dianggap belum semuanya sesuai.

Kredibilitas pemberi informasi tentang usaha pemanfaatan pekarangan di Kabupaten Minahasa berdasarkan lima indikator penilaian: tingkat penguasaan pengetahuan pemberi informasi terhadap informasi usahatani pemanfaatan pekarangan yang diberikan; kemudahan pemberi informasi dalam memberikan pelayanan; sikap empati dari pemberi informasi; kemampuan pemberi informasi dalam berkomunikasi; serta kemampuan dalam mempraktikkan apa yang disuluhkan, semuanya masih berada dalam kategori kurang kredibel. Hal ini disebabkan pemberi informasi (petugas pendamping P2KP dan MKRPL) hanya sekedar menjalankan tugas atau memberi instruksi sesuai dengan petunjuk teknis pelaksanaan program MKRPL dan P2KP, serta informasi yang diberikan belum semuanya sesuai dengan keinginan dan kebutuhan perempuan pemanfaat pekarangan dan kelompoknya.

\section{IMPLIKASI KEBIJAKAN}

Implikasi kebijakan yang bisa dilakukan adalah:

1.Memperbanyak informasi tentang pemanfaatan pekarangan dan pengolahan pangan yang bersumber dari pekarangan melalui media cetak, elektronik (radio dan televisi) serta cyber extension, termasuk media sosial.

2.Kredibilitas petugas/ pemberi informasi dapat ditingkatkan melalui:

a.Petugas lapangan harus lebih dekat dan memahami kebutuhan perempuan dan kelompoknya, serta lebih berpihak pada perempuan pemanfaat pekarangan dan kelompoknya. Bukan sekedar menjalankan tugas tetapi berusaha menjadi bagian dari mereka;

b.Menyusun program-program yang disesuaikan dengan kebutuhan perempuan dan kelompoknya agar kegiatan penyuluhan tepat sasaran dan dapat diaplikasikan oleh perempuan dan kelompoknya, penyusunan rencana kerja dilakukan bersama-sama dengan perempuan dan anggota kelompoknya sebagai acuan dasar para penyuluh dalam menjalankan tugasnya, agar lebih terarah dan tepat waktu;

c.Perlunya komitmen dan dedikasi yang tinggi dari sumber informasi untuk membantu para responden dalam mewujudkan diversifikasi pangan terutama yang berasal dari pekarangan;

d.Pemberi informasi perlu ditingkatkan pengetahuan dan kemampuannya dalam menyampaikan pesan kepada responden (memaparkan ide-ide atau gagasan yang inovatif dengan bukti yang nyata dan benar dengan komunikasi yang baik, melakukan segala sesuatu dengan penuh perhitungan dan perencanaan yang matang);

e.Pemberi informasi perlu ditingkatkan kerajinan dan sikap mau menolong para responden sehubungan dengan masalah-masalah pekarangan dan pengolahan pangan hasil pekarangan yang mereka hadapi;

f.Perlunya kesediaan untuk bersikap mengabdi dan mencintai profesi sebagai agen pembaru sehingga mereka benar-benar akan mendapat kepercayaan dari responden.

g.Peningkatan kemampuan petugas/pendamping (penyuluh) dilakukan melalui: petugas/pendamping harus terus menambah input berupa pengetahuan akan ilmu-ilmu penyuluhan terkini lewat pelatihan atau seminar-seminar, karya tulis atau karya ilmiah, buku-buku, serta memanfaatkan dan mengelola informasi teknologi dan mengkomunikasikan dengan bahasa yang mudah dipahami dan dilakukan secara dialogis.

\section{Daftar Pustaka}

Amanah S, Hastuti EL, \& BasunoE. (2008). Aspek Sosial Budaya dalam Penyelenggaraan Penyu luhan: Ka sus Petani di Lahan Marginal. Jurnal Transdisiplin Sosiologi, Komunikasi, dan Ekologi Manusia, 301 320. 
Andriaty E, \& SetyoriniE. .(2012). Ketersediaan Sumber Informasi Teknologi Pertanian diBeberapa Kabupaten di Jawa . Jurnal Perpustakaan Pertanian, 30-35.

Andriaty E, SankartoBS, \& Setyorini E. (2011). Ka jian Kebutuhan Informasi Teknologi Perta nian diBeberapa Kabupaten di Jawa. JurnalPerpustakaan Pertanian, 20(2), 54-61.

Anwas, O. (2011). Kompetensi Penyuluh Pertanian dalam Memberdayakan Petani. JurnalMatematika, Saintdan Teknologi,46-55.

Asngari, P. (2011). Peranan Agen Pembaharuan/Penyuluh dalam Usaha Memberdayakan (Empowerment) Sumber Daya Manusia Pengelola Agribisnis. Bogor: Ora si Ilmiah Guru Besar Tetap Ilmu Sosial Ekonomi IPB.

Bulu, YG., Sunarru, S., Hariadi, Ageng, S., Herianto, \& Mudiyono. (2008). Pengaruh Modal Sosial dan Keterdedahan Informasi Inovasi terhadap Tingkat Adopsi Inovasi Jagung di Kabupaten Lombok Timur Nusa Tenggara Barat. http://www.pse.litbang.pertani.go.id/ind/pdffile s/JAE \%2029-1a.pdf.

Elian N, Lubis Dp, \& Rangkuti. (2014). Penggunaan Internet dan Pemanfaatan Informasi Pertania n Oleh Penyuluh Pertanian Di Kabupaten Bogor Wilayah Barat. Jurnal Komunikasi Pembangunan, 12(2), $104-$ 109.

Etty, A., \& Setyorini, E. (2012). Ketersediaan Sumber Informasi Teknologi Pertanian diBeberapa Kabupaten di Ja wa . Jurnal Perpustakaan Pertanian, 30-35.

Ghazali, S. (2013). House Garden as a Symbol of Place, Identity and Sense of Belonging for Low-Cost Flat Residents in Urbanizing Malaysia. International Journal of Social Science and Humanity, 171-175.

Hayati. (2015). Partisipasi Perempuan Tani dalam Mencapai Ketahanan Pangan Rumah Tangga (Kasus di Kabupaten LombokTimur Provinsi Nusa Tenggara Barat). Disertasi, IPB, Program Pascasarjana IPB, Bogor.

Hubeis, A. (2012). Relasi Genderdan Ketahanan Pangan. Di dalam: Merevolusi Revolusi Hijau. Pemikiran Guru Besar IPB. Bogor: IPB Press.

Kaye, H. (1997). Mengambil Keputusan Pen uh Percaya Diri. Jakarta: Mitra Utama.

Lubis, D. (2010). Pemanfaatan Teknologi Informa si dan Komunikasi Mendukung Pembangunan Pertanian Berkelanjutan https://repository.ipb.ac.id/handle/123456789/32175.

Manoppo CN, Amanah S, Asngari P, \& Tjitropra noto P. . (2017). PersepsiPerempuan terhadap Pemanfaatan Pekarangan Mendukung Diversifikasi Pangan di Sulawesi Utara . Jurnal Penyuluhan, 13 (1), 40-49.

Manoppo CN, Amanah S, Asnga ri P, \& Tjitropranoto P. . (2018). Women Competence on Home Ga rdening to Support Food Diversification. Pertanika Journal of Social Sciences and Humanities, 26 (2), 825 - 840.
Mardikanto, T. (1993). Penyuluhan Pembangunan Pertanian. . Surakarta: Universitas Sebelas Maret Press.

Matindas, K. (2011). Strategi Komunikasi Petani Sayuran Organik dalam Mencari dan Menggunakan Informasi Berbasis Gender . diserta si, InstitutPertanian B ogor, Bogor.

Mulyandari RS, \& Ananto EE. (2005). Teknik Implementasi Pengembangan Sumber Informasi Pertanian Nasional dan Lokal P4MI. Informatika Pertanian 14.

Mulyandari, R. (2011). Cyber Extension Sebagai Media Komunikasi Dalam Pemberdayaan Petani Sayuran. disertasi, Institut Pertanian Bogor, Bogor .

Nwankwo UM, Kurt J. Peters KJ, \& Wolfgang Bokelmann. (2010). Can Cooperative Membership and Participation Affect Adoption Decisions? Issues for Susta inable Biotechnology Dissemination. The Journal of Agrobiotechnoly Management and Economics.

Parikesit, D. (2003). Integrated Rural Accessibility Planning. Universitas Ga djah Mada.

Prawiranagara, D. (2016). "Penguatan Peran Kelembagaan Petanidalam Peningkatan Kapabilitas Petani Mengelola Inovasi Berbasis Teknologi Informasi". disertasi,, Sekolah Pascasarjana IPB, Bogor.

Rosihan A, \& Rahmah BN. . (2010). Analisis Pemahaman Gizi Ibu Rumah Tangga dalamDiversifikasi Pangan. AGRISE Volume X No. 1 Bulan Januari 2010 . ISSN.

Sharma, P. (2006). Cyber Extension: Information and Communication Technology(ICT) Applications for Agricultural Extension Service Challenges, Oppurtunities, Issues and Strategies. Enhancement of Extension System in Agriculture. APO. .

Sla met, M. (2003). Memantapkan Penyuluhan Pertanian di Indonesia. Membentuk Pola Perilaku Manusia Pembangunan. (I. Y. Sudrajat, Penyunt.) Bogor: Institut Pertanian Bogor Press.

Soekartawi. (2005). Prinsip Dasar Komunikasi Pertanian. Universitas Indonesia.

Sumardjo. (1999). Transformasi Model Penyuluhan Pertanian Menuju Pengembangan Kemandirian Petani. Bogor: Sekolah Pascasarjana IPB.

Suprayitno, A. (2011). "Model Peningkatan Partisipasi Petani Sekitar Hutan dalam Mengelola Hutan Ke miri Rakyat (Kasus Pengelolaan Hutan Kemiri Kawasan Pegunungan Bulusaraung Kabupaten Maros Provinsi Sulawesi Selatan) '. Disertasi, In stitut Pertanian Bogor, Sekolah Pascasarjana.

Suryantini, H. (2004). "Pemanfaatan Informasi Teknologi Pertanian oleh Penyuluh Pertanian: Kasus di Kabupaten Bogor, Jawa Barat.”. Jurnal Perpustakaan Pertanian, 13 (1), 17-23.

Syafiuddin, \& Jahi A. (2008). Hubungan Karakteristik Individu dengan Kompetensi Wirausaha Petani Rumput Laut di Sulawesi Sela tan. Jurnal Penyuluhan, $3(1), 35-44$. 
Tologbonse, D., O.Fashola, and M. Obadiah. (2008). Policy Issues in Meeting Rice Farmers Agricultural Information Needs in Niger State. J. Agric, 12 (2), 84 94.

Van den Ban AW, Hawkins HS. . (1999). Penyuluhan Pertanian. . Yogyakarta: Ka nisius.

Wardhani, A. (1994). Hubungan KarakteristikDemografis dan Motivasi Peternak dengan Pengguna SumberSumber Informasi Tentang Ayam Buras di Desa Cisontrol, Kabupaten Ciasmis. Thesis, Institut Pertanian Bogor, Bogor.

Warpani, S. (2002). Pengelolaan Lalu Lintas dan Angkutan Jalan. Bandung: ITB.

Yumi. (2011). Model Pengembangan Pembelajaran Petani da lam Pengelolaan Hutan Rakyat Lestari (Ka sus di Kabupaten Gunung Kidul Provinsi DI Yogyakarta dan Kabupaten Wonogiri Provinsi Ja wa Tengah). Jurnal Penelitian Sosial dan Ekonomi Kehutanan, 8 (3), 196 210. 